\title{
GESTURE CONTROLLED HUMAN-COMPUTER INTERFACE FOR THE DISABLED
}

\author{
SYSTEM STEROWANIA KOMPUTEREM ZA POMOCA GESTÓW \\ PRZEZNACZONY DLA OSÓB NIEPEŁNOSPRAWNYCH
}

\begin{abstract}
Warsaw University of Technology / Politechnika Warszawska, Warszawa, Poland
Faculty of Electrical Engineering, Institute of Theory of Electrical Engineering, Measurement and Information Systems / Wydział Elektryczny, Instytut Elektrotechniki Teoretycznej i Systemów Informacyjno-Pomiarowych
\end{abstract}

\begin{abstract}
Background: The possibility of using a computer by a disabled person is one of the difficult problems of the human-computer interaction (HCI), while the professional activity (employment) is one of the most important factors affecting the quality of life, especially for disabled people. The aim of the project has been to propose a new HCI system that would allow for resuming employment for people who have lost the possibility of a standard computer operation. Material and Methods: The basic requirement was to replace all functions of a standard mouse without the need of performing precise hand movements and using fingers. The Microsoft's Kinect motion controller had been selected as a device which would recognize hand movements. Several tests were made in order to create optimal working environment with the new device. The new communication system consisted of the Kinect device and the proper software had been built. Results: The proposed system was tested by means of the standard subjective evaluations and objective metrics according to the standard ISO 9241-411:2012. The overall rating of the new HCI system shows the acceptance of the solution. The objective tests show that although the new system is a bit slower, it may effectively replace the computer mouse. Conclusions: The new HCI system fulfilled its task for a specific disabled person. This resulted in the ability to return to work. Additionally, the project confirmed the possibility of effective but nonstandard use of the Kinect device. Med Pr 2017;68(1):11-21
\end{abstract}

Key words: quality of life, physical disability, employment, gesture control, human-computer interaction, Microsoft Kinect

\section{STRESZCZENIE}

Wstęp: Możliwość korzystania z komputera przez osoby niepełnosprawne jest jednym z trudniejszych problemów interakcji człowiek-komputer, natomiast aktywność zawodowa (zatrudnienie) należy do najważniejszych czynników wpływających na jakość życia, szczególnie osób niepełnosprawnych. Celem pracy było zaproponowanie nowego systemu sterowania komputerem pozwalającego na powrót do pracy osobom, które straciły możliwość standardowej obsługi komputera. Materiał i metody: Podstawowym założeniem nowego systemu było zastąpienie standardowej myszy komputerowej urządzeniem, które nie wymaga wykonywania precyzyjnych ruchów ręką i palcami. W pracy skorzystano z kontrolera Microsoft Kinect jako urządzenia rozpoznającego ruchy rąk. Przeprowadzono badania wstępne w celu określenia optymalnych warunków pracy nowego urządzenia i opracowano nowy system składający się z kontrolera Kinect i oprogramowania do niego. Wyniki: System został przetestowany z wykorzystaniem standardowej oceny subiektywnej i obiektywnej zgodnie z normą ISO 9241-411:2012. Ogólna ocena nowego systemu wskazuje na akceptację proponowanego rozwiązania przez badanych. Obiektywne testy pokazują, że nowy system - choć jest nieco wolniejszy od standardowego - może skutecznie zastąpić mysz komputerową. Wnioski: Nowy system interakcji człowiek-komputer spełnił swoje zadanie dla konkretnej osoby niepełnosprawnej, czyli umożliwił sterowanie komputerem, a tym samym powrót do pracy. Dodatkowo badanie potwierdziło możliwość skutecznego niestandardowego wykorzystania urządzenia Kinect. Med. Pr. 2017;68(1):11-21

Słowa kluczowe: jakość życia, niepełnosprawność ruchowa, zatrudnienie, sterowanie gestami, komunikacja człowiek-komputer, Microsoft Kinect

Corresponding author / Autor do korespondencji: Dariusz J. Sawicki, Warsaw University of Technology,

Faculty of Electrical Engineering, Institute of Theory of Electrical Engineering, Measurement and Information Systems, Koszykowa 75, 00-662 Warszawa, Poland, e-mail: dariusz.sawicki@ee.pw.edu.pl

Received: July 6, 2016, accepted: September 6, 2016

\section{INTRODUCTION}

One of the most important things in evaluating the quality of life is professional activity (employment). The authors of the First European Quality of Life Survey [1] underline the importance of employment for subjective well-being. In other words, a satisfying job means a great life. Although a work-life balance (the relation- 
ship between work and family life) plays a significant role in determination of a life satisfaction, the study shows that the job satisfaction, especially in the case of a disabled person, is the key aspect. The analysis based on the independent research shows that the professional activity of a disabled person is one of the major elements of social functioning [2]. Moreover, the study shows that the quality of life of a disabled person depends heavily on the aforementioned employment and age [3]. Therefore, the loss of work due to an accident drastically changes the quality of life, and is usually followed by the additional negative sociological consequences, such as decline in the number of social contacts. This process deepens with the longer and longer time of inactivity [2].

On the one hand, the widespread usage of computers in the office work causes the need to increase one's qualifications. On the other hand, it reduces the amount of job opportunities for people who cannot operate a computer. In order to increase employability among disabled people, modern operating systems are constructed in such a way that they may be operated by the visually impaired, deaf, or by means of a keyboard instead of a mouse. However, despite these improvements, the loss of ability to handle a computer mouse reduces productivity. It should be noted that difficulties in the use of manipulators, such as a mouse, occur not only as side effect of an accident but also because of various types of conditions e.g., carpal tunnel syndrome (CTS) [3]. Of course, the level of quality of life is affected by many other factors, and above all, the low level of education and place of residence (a small town) play a role [4]. This has been particularly important in recent years, when it has been observed that employees more frequently perform work at home as an alternative to daily work at an office. However, in this case a very important factor is efficiency of one's computer work.

Despite the development of various types of the human-computer interaction (HCI) equipment, computer usage by disabled people with a hand dysfunction may still pose problems. If the range of motion becomes insufficient to use a computer mouse or other pointing devices (a trackball, joystick, etc.), this in practice causes the inability to use a computer.

Since 1973 a computer mouse has been the most common HCI device used in order to control a computer [5]. As a matter of fact, since the time when Xerox introduced the first computer mouse, little has changed in terms of using a mouse to move the cursor on the computer screen. Although other HCI devices serving the same purpose had been proposed, e.g., a trackball and joystick, they have not replaced the computer mouse. The latest invention - a touchpad, is a replacement of a traditional computer mouse for laptops. Due to the usage of multi-touch surface, a touchpad is able to recognize some simple touch gestures. This makes it easier to control and to speed up communication with the computer. Unfortunately, none of these solutions allows for a convenient usage of the computer for a disabled person with a hand dysfunction.

A significant number of devices, the purpose of which is to detect and recognize the movements made by a human, could be found. The perfect example is offered by the devices which recognize the gestures used in various types of the $\mathrm{HCI}$, e.g., the Microsoft Kinect (Microsoft, USA) [6], Leap Motion (Leap Motion Inc., USA) [7] and Myo Gesture Control Armband (Thalmic Labs Inc., Canada) [8]. There are also many different HCI solutions designed for disabled people. Besides hand gestures, position of face and head may also be a source of information in the HCI. Within the work of Mandal et al. [9], after an initial selection of skin color, the face/head poses are used for the analysis purposes. Strumiłło and Pajor [10] described the similar system based on face recognition. The analysis of head and mouth is used in computer access for a disabled person [11]. Authors of the solutions based on the analysis of head's poses, often added the simple analysis of the closed and opened eyes. Advanced recognition of eyes image, such as an eye tracking, may also be useful in the HCI together with detections of head position. The survey of such solutions may be found in the paper prepared by Al-Rahayfeh and Faezipour [12]. The survey of eye tracking method was presented by Singh and Singh [13].

Kinect, designed by Microsoft, is an example of a very interesting solution created for the entertainment industry. Moreover, the construction of the device allows to use it for a higher purpose. It is possible due to the Kinect's ability to identify the body parts location with the precision required by the motion capture usage. It was confirmed by D'Orazio et al. [14]. They overwind different devices and methods used for gesture recognition purposes and confirm that $\mathrm{Ki}$ nect is one of the most serious modern devices of this type.

The article [15] includes the description of anthropometry for measuring body composition in human clinical research and practice. It is worth noticing that in 
order to recognize the location, Kinect does not require a patient to wear additional hardware that could limit his/her movement [16]. That means that Kinect is a lowcost system which slowly becomes a standard in rehabilitation [17-19]. Authors of such solutions appreciated not only the usage of virtual reality $[17,18,20]$ but, first of all, the possibility of creating a unique real-time biofeedback $[17,18,21]$. Thanks to that it is possible to determine whether the patient's movements have reached the rehabilitation standards. It allows the therapist to view rehabilitation progress and correct the therapy. The analysis of the Kinect possible medical usage was characterized by Levac et al. [17]. Based on other publications, the authors of this article list possible solutions of medical problems such as: stroke, multiple sclerosis, cerebral palsy (CP), ataxia, adolescents with ankle sprains. Some more issues should be taken into account: motor impairments [21], Parkinson's disease [22], total knee replacement (TKR) [18], which were descripted in other publications.

The Kinect's advantages, which were appreciated in medicine, had become the primary reason for which this device was used in the solution described in our article.

The aim of this project has been to develop a simple and effective HCI system to control the computer with hand gestures made by the user on or above the surface of the desk. The device was designed for an employee who, as a result of the accident, lost the ability to perform movements of 2 fingers and to perform precise movements of the wrist. Since that time, he had had great difficulties in performing precise hand movements, which did not allow him to use the standard devices to control the computer. The aim has been to develop a solution that would replace all the functions of a standard computer mouse without the need for painful movements of a hand, thereby to allow the user to communicate with a computer effectively and without discomfort. The solution has been dedicated for a specific person but it is possible to use for many other purposes.

\section{MATERIAL AND METHODS}

\section{Basic requirements}

The following assumptions were made. The proposed solution should:

give the opportunity to control the system with the usage of gestures on a standard desk,

be intuitive for the user, be implemented with the usage of computer hardware widely available at home. For example, these could be devices commonly used for playing computer games. This approach will allow the user to work at home and one device will be used for a variety of purposes.

This solution has been designed for people with a hand dysfunction, which does not allow for performance of movements with the usage of standard devices (such as: a mouse, trackball). The main idea has been to avoid a typical hand position necessary for the use of the mouse, which is painful for the user, while working with the device. This problem may be easily observed in the case of usage of a computer mouse but also in the case of usage of a touchpad or a trackball. The user has to lay his hand in an appropriate (specific) manner. Standard devices require to take in a hand (to grip) a device (a mouse, trackball, and joystick) and additionally perform precise movements with fingers. The proposed solution allows for the replacement of the mouse, without the necessity to lay a hand in an uncomfortable position.

Several different solutions exist in the personal computer (PC) market. Some of those have been rejected because they require additional elements folding and self-assembly. This did not guarantee reliable operation and repeatability of the results of the implementation. All standard pointing devices such as a trackball or joystick were rejected because they required holding the controlling element in a hand. After reviewing the existing solutions, it was decided to use the Microsoft's Kinect motion controller for recording the position of the hand of a man.

\section{New dedicated HCI system}

The decision to select the Kinect, as a device to recognize hand movements, was mainly taken due to the device's very good recognition of body movements. The Kinect was developed in order to be used for console games, which requires precision in move detection. Its abilities were also confirmed by tests done by the Microsoft company [19] and other independent studies [14]. In particular, it was confirmed in medical applications [15,17].

The other decisive reason has been the fact that Kinect is much more technologically advanced than its competitive solutions. For example, a device Myo created by Thalmic Labs (Canada) [8] requires the usage of a hand-held sensor which detects movement whereas the Kinect tracks person's moves without the need to 
set up additional hardware on the person who uses it. The Kinect is a low-cost type of a device, which means that it may be often found at patients' houses due to its primarily entertainment application. Therefore, rehabilitation does not require from a patient to buy new devices but to get appropriate software [17]. Moreover, even the solution which is described here could be used as entertainment. In addition, the software development kit (SDK) provided by Microsoft allows for the near range feature in order to track people close to the sensor [23]. Additionally, it is worth pointing out the seated tracking mode, designed to track a person sitting on a chair or couch or to track people, whose lower body is not entirely visible to the sensor.

The system consists of 2 main parts: the Microsoft Kinect device and proprietary software used for detecting and understanding movements of the hand, performed on the desk or flat surface. The software was designed with the usage of the Windows Presentation Foundation, which is a graphical subsystem for rendering user interfaces, and C Sharp (C\#) which is a multiparadigm programming language, in order to create a fully functional HCI system. This project also paid attention to the ease of restoring positions in various operating conditions. The developed solution is compatible with all PC computers that use Windows 7 or higher. All the necessary drivers needed to run the device will be installed by the Windows Update system service because the Kinect is detected as a set of devices. In some cases, problems with the installation of drivers occurred. These problems were mainly caused by changes in the default settings (the above mentioned system service). They may be solved by installing the entire SDK [24] which contains all the necessary components and which may detect the Microsoft Kinect and launch the drivers correctly.

\section{Working environment}

\section{of the new HCI system}

The Microsoft Kinect is a typical device for gamers. The usage of it as a professional pointing device required a design of new working conditions of the device. In order to define this new working environment, a set of simple tests and analysis was conducted. They allowed to calibrate the device and adapt the program to the range of movements performed by the user. In addition, the tests helped to determine the environmental conditions that should be met or which are the most appropriate and most relevant for the operation of the Microsoft Kinect. The decision to choose the user's right hand was dictated by the fact that the person for whom this project was designed was right-handed. Therefore, it was easier for the patient to get used to the new way of controlling a computer. Of course, the universality of this solution allows to construct an analogical device for a left-handed person.

The first important task, which had undergone a test of the system, was the analysis of the size of the working area used for performing the movements of the right hand of the user. This test was carried out on the desk with four separate working areas (as shown in the Figure 1): $30 \times 30 \mathrm{~cm}, 40 \times 40 \mathrm{~cm}, 50 \times 50 \mathrm{~cm}$ and $55 \times 55 \mathrm{~cm}$. Mapping the scale of the cursor was picked in such a way as to allow any hand movements within the working area. Due to the fact that the experience which was tested was purely subjective, the scale which was used had to be simple and understandable. In both cases, a simple, three-step scale - for mapping the scale of the cursor and for accuracy of movements: small, moderate, high was used.

The 1st test was conducted for 3 participants, 2 healthy men and 1 healthy woman who were 20,24 and 25 years old, each one evaluated all of the workspaces. All participants used the computer every day at work for office tasks. The task consisted of simple operations on the screen (move, drag and drop, etc.) with the control of the target position (coordinates) for each element. The aim was to perform the task as accurately as possible. Users rated the quality of transferring between hand movements and cursor movements. Average assessments of the quality of work are presented in the Table 1. After analyzing the results from the table it may be seen that there is the relationship between the size of the surface on which the user performed hand

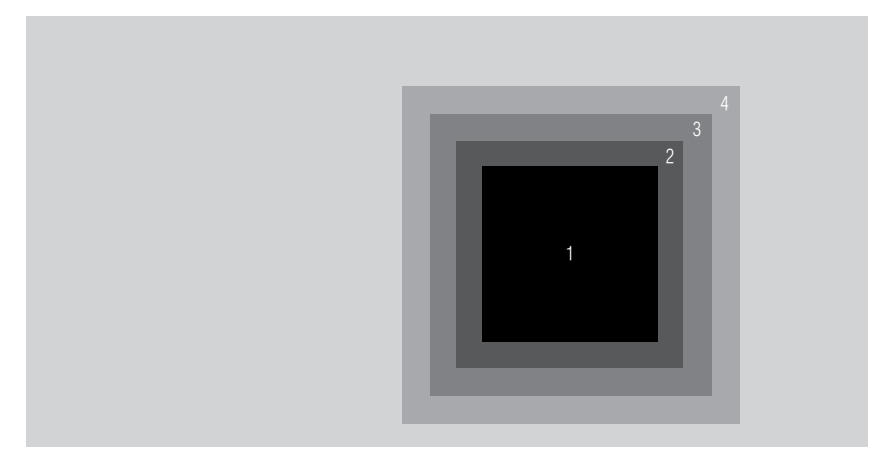

$1-30 \times 30 \mathrm{~cm}, 2-40 \times 40 \mathrm{~cm}, 3-50 \times 50 \mathrm{~cm}, 4-55 \times 55 \mathrm{~cm}$.

Fig. 1. Working area on the desk in the study of the gesture controlled human-computer interface for the disabled Ryc. 1. Przestrzeń robocza na biurku w badaniu systemu sterowania komputerem za pomocą gestów przeznaczonego dla osób niepełnosprawnych 
Table 1. Subjective assessment of the gesture controlled human-computer interface for the disabled and working area on the desk

Tabela 1. Subiektywna ocena działania systemu sterowania komputerem za pomocą gestów przeznaczonego dla osób niepełnosprawnych a wielkość przestrzeni roboczej na biurku

\begin{tabular}{cll}
$\begin{array}{c}\text { Working area } \\
\text { Przestrzen } \\
\text { robocza } \\
{[\mathrm{cm}]}\end{array}$ & $\begin{array}{c}\text { Accuracy of hand/ } \\
\text { cursor movements } \\
\text { Precyzja ruchów } \\
\text { ręki/kursora }\end{array}$ & $\begin{array}{c}\text { Mapping scale of cursor } \\
\text { movements } \\
\text { Skala odwzorowania } \\
\text { ruchów kursora }\end{array}$ \\
\hline $30 \times 30$ & small / mała & $\begin{array}{l}\text { large / duża } \\
\text { moderate / średnia }\end{array}$ \\
$40 \times 40$ & small / mała & moderate / średnia \\
$50 \times 50$ & moderate / średnia & small / mała \\
$55 \times 55$ & high / wysoka &
\end{tabular}

movements and the accuracy of the movements of the cursor. The larger the working area, the higher accuracy of the movement, and the better control of the cursor (smaller movement).

For each working area appropriate scaling was necessary for the proper operation of the Microsoft Kinect. This feature is very important for the proper functioning of the whole system. As a result, the user doing the small movements of the hand can move the cursor over a larger area of the screen. Users assessed that the most convenient working area represented a size of $50 \times 50 \mathrm{~cm}$ or more (Table 1). The scaling between the hand movements and the movements of the cursor allowed for the performance of precise movements and clicks on the selected items without worrying about accidentally changing the position of the cursor. Clicking is done by pointing the selected item and waiting for a period of time (counted in seconds). After the selected time passes, software performs a click. Clicking is performed only once at the moment of indication of the element. The next click is executed after the movement of the hand.

The bigger the area, which has been used, the better the results. However, a compromise is needed because the larger working area, the greater hand movements are needed. The usage of space bigger than $55 \times 55 \mathrm{~cm}$ makes work uncomfortable. The area of $50 \times 50 \mathrm{~cm}$ in size was chosen as the most comfortable for work with the HCI system.

The simple and preliminary test (with results presented in the Table 1) was subjective assessment realized by the participants. This test facilitated the analysis of the proper position of the Kinect device in the next step. The 2nd test concerned the Kinect angle of operation and its position relative to the desk. The problem arose mainly from the fact that the Kinect was used in

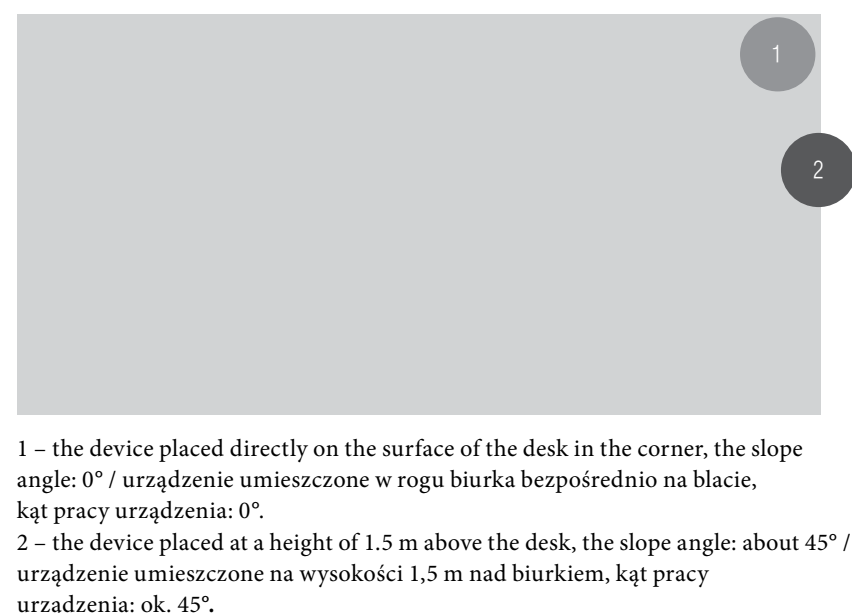

urządzenia: ok. $45^{\circ}$.

Fig. 2. Placing relative to the work station of the gesture controlled human-computer interface for the disabled with Kinect device

Ryc. 2. Umiejscowienie względem stanowiska pracy urządzenia Kinect do sterowania komputerem za pomocą gestów przeznaczonego dla osób niepełnosprawnych

an unusual way - completely different from the typical use by the players. To properly detect the human figure and to begin tracking the movements of the right hand of a user, the Microsoft Kinect has to "see" the user at least from the waist up [25]. From the information provided by the manufacturer, it may be concluded that the device needs to see both hands in order to operate in a proper way. After many preliminary experiments, the placement of the Kinect device directly on the desk was rejected. Even the position relatively far from the user - a desktop corner (position 1 in the Figure 2) did not make it possible to work with the Kinect properly. The placement (position 2 in the Figure 2) was chosen as the best solution, the device was hanging $1.5 \mathrm{~m}$ above the desk.

The 2nd test confirmed the known fact that the decisive factor for the correct detection of the user was the appropriate placement of the Kinect device relative to the user. In addition, during testing it was found that the user had to be seated at least $1 \mathrm{~m}$ away from the device for it to detect the movement of his/her right hand. In this case the proposed solution worked the best.

The last test was conducted to check the extent to which sunlight (or artificial light in the room) affected the correct operation of the Microsoft Kinect, and thus the operation of the whole HCI system. On the manufacturer's website the information that the device may have problems with the sunshine may be found [26]. Tests were performed in four different con- 
ditions during the time of the day with the highest sun exposure and in the evening:

- highest sun exposure, curtains of the window not used,

highest sun exposure, the windows obscured halfway,

highest sun exposure, windows fully obscured,

the night, artificial light sources in the room.

The tests, which were carried out consecutively, concerned: verification of the optimal workspace used for performing the movements of the right hand of the user, and verifying the optimum tilt angle of the device in relation to the working surface. The last test which was performed was aimed to verify the effect of the light on the operation of the proposed solution. The tests were repeated twice in order to verify the results. All results are presented in the Table 2.

In all 4 cases the illuminance (in $1 \mathrm{x}$ ) was measured on a desk in accordance with the standard: light and lighting; lighting of work places [27]. Obtained results are presented in the Table 2. Taking the result into consideration it may be seen that in all the cases the lighting conditions allow for convenient work [27], although in the case of fully obscured, illuminance level could be higher. It may be assumed that the difficulties of the proper operation of the device should be associated with a high value of illuminance - light reflected from the surface of the desk in the Kinect direction - which means high value of flux reaching the Kinect sensors. However, such assessment would require a more thorough study, which in principle should be implemented by the equipment manufacturer.
From the technical point of view, the aim of the tests was to assess the proper conditions for the working device. It also considers the working area. In practice it means that the user has no boundaries as to the size of the working area as long as the device works properly.

During testing, it was found that despite some problems, the impact of sunlight on the operation of the device was relatively small. This was caused by the fact that the tests were held in a closed room, not in the open area. However, some problems with the detection of the movement of the user's right hand could be seen at a time when the sun operates directly on the desk through the uncovered window.

\section{RESULTS}

As a result of the research it was obtained that the new HCI system would replace all the functions of a standard computer mouse and allow to operate a computer with the usage of gestures. Additionally, after analyzing the preliminary tests, the defined optimal working environment for this system was determined. The appearance of the work station with the Kinect device as the completed system, is presented in the Figure 3 .

The 1st user, who tested the completed system, was a person for whom the project had been created. After a short period of adaptation (a few days), it was found that the device had not only met expectations but had also given satisfaction with the possibility of re-using a computer. However, such assessment of the operation

Table 2. Working of the gesture controlled human-computer interface for the disabled and illuminance on the desk Tabela 2. Działanie systemu sterowania komputerem za pomocą gestów przeznaczonego dla osób niepełnosprawnych a natężenie oświetlenia na biurku

\begin{tabular}{|c|c|c|}
\hline $\begin{array}{l}\text { Light conditions } \\
\text { Warunki oświetlenia }\end{array}$ & $\begin{array}{c}\text { Average illuminance } \\
\text { on the desk } \\
\text { Średnie natężenie } \\
\text { oświetlenia na biurku } \\
\text { [lx] }\end{array}$ & $\begin{array}{l}\text { Operation of the system } \\
\text { Praca systemu }\end{array}$ \\
\hline $\begin{array}{l}\text { Highest sun exposure, window not obscured / Najwyższy } \\
\text { poziom nasłonecznienia, okno niezasłonięte }\end{array}$ & 3800 & $\begin{array}{l}\text { sometimes the detection of hand movements is not working, } \\
\text { operation difficult / detekcja ruchu rąk czasami nie działa, } \\
\text { praca utrudniona }\end{array}$ \\
\hline $\begin{array}{l}\text { Highest sun exposure, window obscured halfway / Najwyższy } \\
\text { poziom nasłonecznienia, okno zasłonięte w połowie }\end{array}$ & 1000 & operations correct / operacje realizowane poprawnie \\
\hline $\begin{array}{l}\text { Highest sun exposure, window fully obscured / Najwyższy } \\
\text { poziom nasłonecznienia, okno zasłonięte całkowicie }\end{array}$ & 220 & operations correct / operacje realizowane poprawnie \\
\hline $\begin{array}{l}\text { Night, artificial light source in the room / Noc, sztuczne źródło } \\
\text { światła w pokoju }\end{array}$ & 270 & operations correct / operacje realizowane poprawnie \\
\hline
\end{tabular}




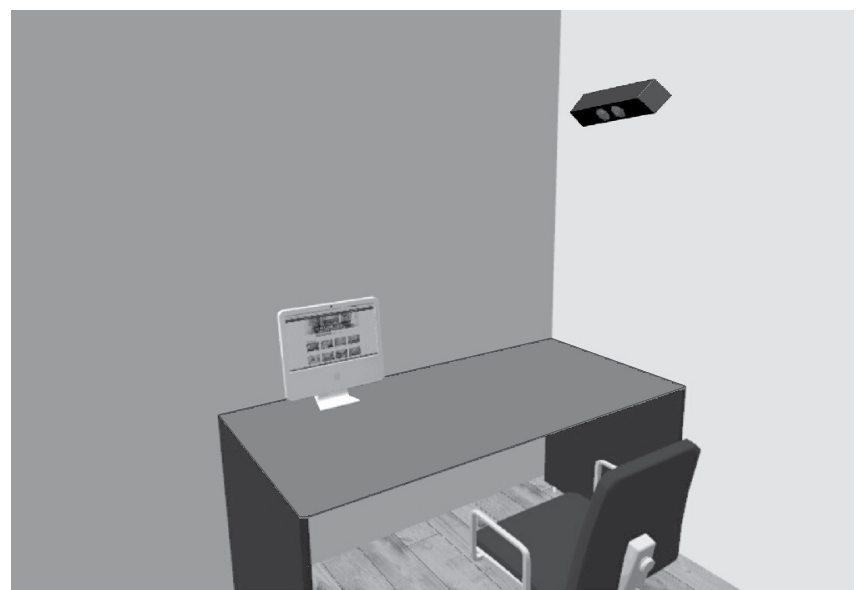

The device is placed above the desk at a height of $1.5 \mathrm{~m}$, the slope angle: about $45^{\circ}$ / Urządzenie jest umieszczone nad biurkiem na wysokości 1,5 m, kąt pracy: ok. $45^{\circ}$

Fig. 3. Work station with the gesture controlled human-computer interface for the disabled with Kinect device

Ryc. 3. Stanowisko pracy z urządzeniem Kinect do sterowania komputerem za pomocą gestów przeznaczonym dla osób niepełnosprawnych

was not entirely objective, so the device was tested in the same way as the new HCI devices were tested, with the usage of requirements of the relevant ISO standards.

The objective test of the completed system as a set of experiments on a small group of 5 participants was carried out. The group consisted of 3 healthy men and 2 healthy women, aged between 25-60 years old, with the average age of 37 years old. All participants used the computer every day at work for office tasks. The proposed solution was new and unknown to all participants. In the experiments participants used the new HCI system and a computer with a monitor. The monitor which was used had 24" $(609.6 \mathrm{~mm})$ screen and Full HD resolution $(1920 \times 1080)$. The distance between the participants and the screen ranged $60-70 \mathrm{~cm}$. The aim of the 1st experiment was to recognize the device and to perform a subjective evaluation. Participants evaluated the operation of the new system using a 5-step subjective scale. Methods consistent with the standard ISO 9241411:2012 were used [28]. Evaluation was carried out in 3 groups of parameters. In each one, 3 parameters were assessed. Additionally, the overall assessment of the device was performed. The scale 1-5 (5 steps) was used. The full set of parameters that were evaluated, was as follows:

the cursor control:

- speed - from unacceptable (1) to acceptable (5),

- accuracy - from very inaccurate (1) to very accurate (5),
- work comfort - from very uncomfortable (1) to very comfortable (5),

the gesture control:

- speed - from unacceptable (1) to acceptable (5),

- accuracy - from very inaccurate (1) to very accurate (5),

- work comfort - from very uncomfortable (1) to very comfor table (5),

the text entry (an on-screen keyboard):

- speed - from unacceptable (1) to acceptable (5),

- accuracy - from very inaccurate (1) to very accurate (5),

- work comfort - from very uncomfortable (1) to very comfortable (5),

the overall operation of input device - from very difficult to use (1) to very easy to use (5).

The aim of the 2nd experiment was to compare efficiency of a text input when working with a typical computer mouse, and when working with the new system. Standard metrics for evaluation of text entry were used $[29,30]$.

The task presented to the participants of the experiment was to rewrite an unknown text using the screen keyboard. The main aim was to rewrite as many characters as possible and to make as few mistakes as possible. The experiment consisted of 2 parts: in the 1st one the participants performed the task using a standard computer mouse, in the 2nd part they performed the task using the new system (the gesture control and Kinect). To enter the text in our solution participants had to use the on-screen keyboard, which was displayed in the middle bottom of the screen. The size of a single button was $50 \times 50 \mathrm{px}$ (with the screen size 24" $(609.6 \mathrm{~mm}$ ) and the resolution $1920 \times 1080)$. Both tasks lasted $10 \mathrm{~min}$. In the experiment, many factors were assessed according to widely used metrics $[29,30]$. Factors which were assessed:

correct keystrokes (C),

incorrect fixed (IF),

incorrect and not fixed (INF),

fixes (F),

number of words per minute (WPM),

minimum string distance error rate $(\mathrm{MSD}=\mathrm{INF} /$

$(\mathrm{C}+\mathrm{INF}) \times 100 \%)$,

keystrokes per character $(\mathrm{KSPC}=(\mathrm{C}+\mathrm{INF}+\mathrm{IF}+\mathrm{F}) /$ (C+INF)),

corrected error rate $(\mathrm{CER}=\mathrm{IF} /(\mathrm{C}+\mathrm{INF}+\mathrm{IF}) \times 100 \%)$, not corrected error rate $(\mathrm{NCER}=\mathrm{INF} /(\mathrm{C}+\mathrm{INF}+\mathrm{IF}) \times$ $100 \%)$,

total error rate $(\mathrm{TER}=\mathrm{CER}+\mathrm{NCER})$. 
Table 3. Subjective assessment of the gesture controlled human-computer interface for the disabled Tabela 3. Subiektywna ocena systemu sterowania komputerem za pomocą gestów przeznaczonego dla osób niepełnosprawnych

\begin{tabular}{|c|c|c|c|c|c|c|}
\hline \multirow[t]{2}{*}{$\begin{array}{l}\text { Parameter } \\
\text { Parametr }\end{array}$} & \multicolumn{6}{|c|}{$\begin{array}{l}\text { System assessment by respondents } \\
{[\mathrm{pts}]} \\
\text { Ocena systemu przez respondentów } \\
{[\mathrm{pkt}]}\end{array}$} \\
\hline & $\mathrm{R} 1$ & $\mathrm{R} 2$ & R3 & $\mathrm{R} 4$ & R5 & $\mathrm{M}$ \\
\hline \multicolumn{7}{|l|}{ Cursor control / Sterowanie kursorem } \\
\hline accuracy / precyzja & 4 & 3 & 2 & 4 & 5 & 3.6 \\
\hline work comfort / wygoda pracy & 3 & 3 & 3 & 5 & 4 & 3.6 \\
\hline \multicolumn{7}{|l|}{ Gesture control / Sterowanie gestami } \\
\hline speed / szybkość & 3 & 2 & 2 & 4 & 3 & 2.8 \\
\hline speed / szybkość & 4 & 3 & 3 & 4 & 5 & 3.8 \\
\hline accuracy / precyzja & 4 & 3 & 2 & 4 & 4 & 3.4 \\
\hline work comfort / wygoda pracy & 4 & 3 & 4 & 4 & 4 & 3.8 \\
\hline Overall operation of input device / Ogólne działanie systemu & 4 & 3 & 3 & 4 & 3 & 3.4 \\
\hline
\end{tabular}

R1-5 - respondents / respondenci.

$\mathrm{M}$ - mean / średnia.

The results of the experiments are summarized in the Tables 3 and 4.

\section{DISCUSSION}

The opinion of the person for whom the system was built, was very positive. However, it cannot be treated as an objective assessment. As we know objective evaluation is a collection of dry and cold indices that do not take into account the emotional relationship to the product. Even if the product allows for the return to work. Therefore, only the objective assessment based on the international standards is reliable.

Analyzing the results which have been collected; we may conclude that the objective parameters for the new device are worse than for the mouse. Operation with the usage of the Kinect is slower than the usage of the mouse, and at the same time users made more errors (increased TER). Having said that, it came as a surprise that the KSPC factor grew slightly. This means that typing one letter correctly requires a similar number of key/movements. Because of that we cannot surely say that the new device is worse and less effective.

The overall rating of the new HCI system at the level of 3.4 shows the acceptance of the solution. The ability to control the cursor position was assessed at the level of 3.6. Similarly, users evaluated the possibility of entering text using the on-screen keyboard. The usage of gestures got poor results. In addition, users complained about the discomfort caused mainly by the relatively slower operation in comparison to a mouse, which they were accustomed to.

It should also be noted that the users, who participated in the experiment, had practical experience in the use of a standard computer mouse. They had handled the computer mouse every day and had had it mastered perfectly. In contrast, they were using the new solution for the first time. In this case, the decrease in speed and increase in errors is justified. Thus, taking into account the small increase of the KSPC, it may be assumed that the experience in the use of the new device would get much better results.

It is also worth noticing that the aim of the thesis has been to find a solution to a particular problem and replace a computer mouse with the different HCI solution. Moreover, it was assumed that the new solution would be as close to the usage of the standard computer mouse as possible. Therefore, the tests which were conducted were a comparison of the new solutions only in relation to a standard computer mouse usage. 


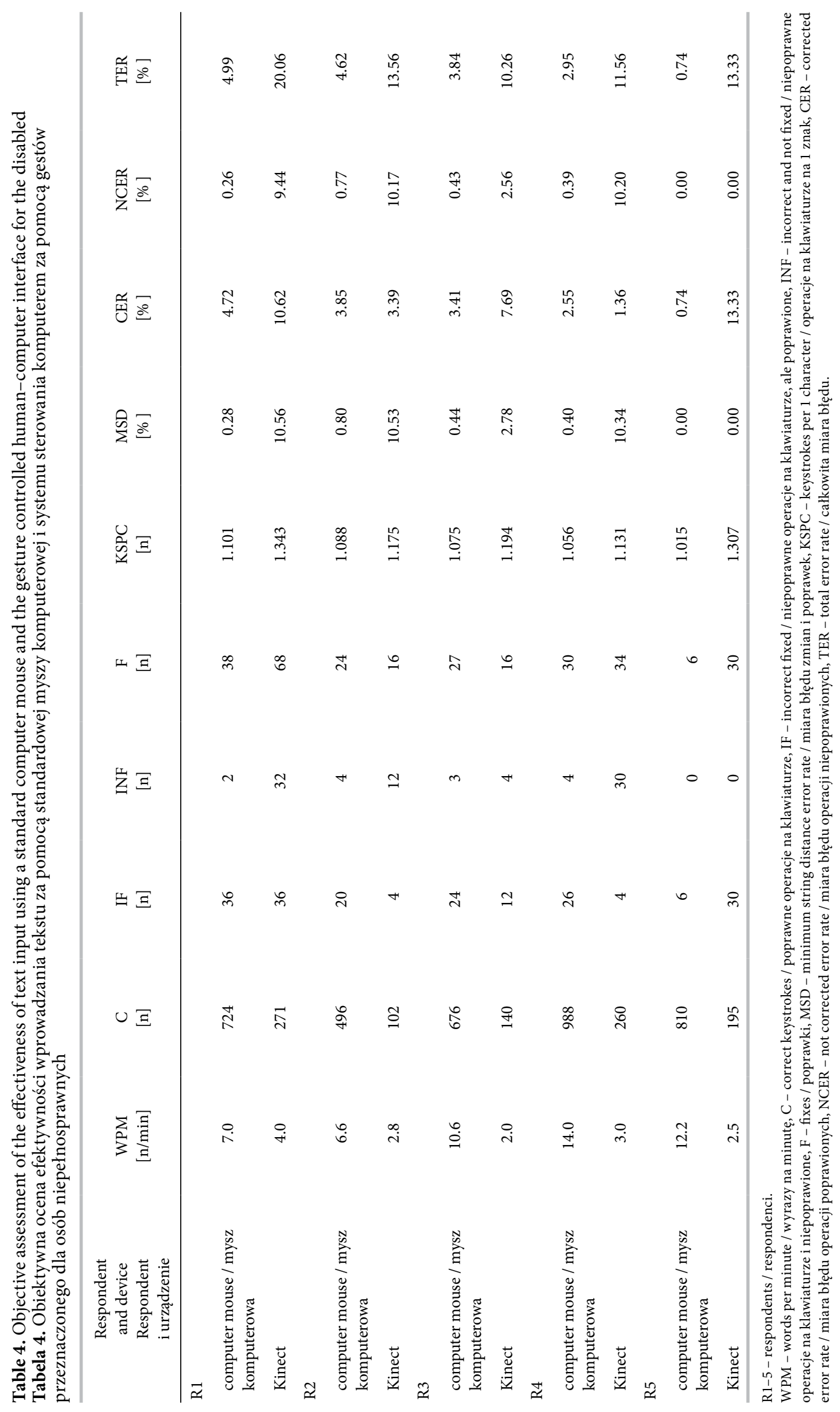




\section{CONCLUSIONS}

This thesis has presented the replacement for a computer mouse, the new HCI system, which uses the Microsoft Kinect device in a non-standard way. The performed tests have shown that Kinect is well suited for identifying gestures to control, and thus gives the possibility to replace the standard mouse. In order to correctly use the system, we have to put the Kinect far enough, so that it may detect the user from the waist up. In addition, it is worth noticing that the area of about $50 \times 50 \mathrm{~cm}$, necessary to work, is not very big, so the solution may be applied on a standard desk.

A set of tests on a small group of participants was carried out. Users pointed out that the work compared to using a standard mouse was distinctly slower. This was confirmed by an objective test. However, subjective tests showed acceptance of the new solution and, which was very important, it was also confirmed by an objective test. Taking into account the results of an objective evaluation of the new system, it may be assumed that the experience with new system would allow working more efficiently.

It is worth saying that the assignment was carried out in accordance with the assumptions. A device, that was used, had been in common usage and had not required any additional modifications implemented by the user. At the same time the possibility of non-standard and effective use of the Microsoft's Kinect has been confirmed.

The new HCI system was dedicated to a specific person and fulfilled its role. It was dedicated to a person who was unable to use the mouse or any other classic HCI device without pain. It is hard to change the quality of life in this case but you may certainly say that the new system allows for the continuation of previous work - the work performed before the accident. And it certainly affected the quality of life of the patient. The project was dedicated to a particular type of disability. However, we believe it may be used in many other cases of disability or limited abilities of the hand movement. What is more, the new HCI system may be used by all those for whom the use of a standard computer mouse is inconvenient, or difficult.

\section{REFERENCES}

1. Wallace C, Pichler F, Hayes BC. First European Quality of Life Survey: Quality of work and life satisfaction. Dublin: European Foundation for the Improvement of Living and Working Conditions; 2007.
2. Pawłowska-Cyprysiak K, Konarska M, ŻołnierczykZreda D. Self-perceived quality of life of people with physical disabilities and labour force participation. Int J Occup Saf Ergon. 2013;19(2):185-93, https://doi.org/ 10.1080/10803548.2013.11076977.

3. Lewańska M, Wągrowska-Koski E, Walusiak-Skorupa J. [Etiological factors for developing carpal tunnel syndrome in people who work with computers]. Med Pr. 2013;64(1):37-45, https://doi.org/10.13075/mp.5893/ 2013/0005. Polish

4. Pawłowska-Cyprysiak K, Konarska M, ŻołnierczykZreda D. [Determinants of quality of life people with physical disability]. Med Pr. 2013;64(2):227-37, https:// doi.org/10.13075/mp.5893/2013/0019. Polish.

5. Computer Hope [Internet]. Riverton: Computer Hope; 2016 [cited 2016 Aug 3]. When and who invented the first computer mouse? Available from: http://www.computerhope.com/issues/ch001083.htm.

6. Košič K, Arzenšek B, Kuhar S, Vogrinčič M. Towards new user interfaces based on gesture and sound identification. In: Budimac Z, editor. SQAMIA 2013: Proceedings of the 2nd Workshop of Software Quality Analysis, Monitoring, Improvement, and Applications; 2013 Sep 15-17; Novi Sad, Serbia. Novi Sad: Department of Mathematics and Informatics Faculty of Sciences, University of Novi Sad; 2013. p. 45-52.

7. Guna J, Jakus G, Pogačnik M, Tomažič S, Sodnik J. An analysis of the precision and reliability of the Leap Motion Sensor and its suitability for static and dynamic tracking. Sensors. 2014;14(2):3702-20, https://doi.org/10.3390/s14 0203702.

8. Nuwer R. Armband adds a twitch to gesture control. New Scientist 2013;217(2906):21, https://doi.org/10.1016/S02 62-4079(13)60542-4.

9. Mandal B, Eng H-L, Lu H, Chan DWS, Ng Y-L. Non-intrusive head movement analysis of videotaped seizures of epileptic origin. In: Institute of Electrical and Electronics Engineers. Proceedings of the 34th Annual International Conference of the IEEE Engineering in Medicine and Biology Society (EMBS); 2012 Aug 28 - Sep 1; San Diego, USA. The Institute; 2012. p. 6060-63, https://doi. org/10.1109/embc.2012.6347376.

10. Strumiłło P, Pajor T. A vision-based head movement tracking system for human-computer interfacing. In: Institute of Electrical and Electronics Engineers. Proceedings of the New Trends in Audio and Video Signal Processing Algorithms, Architectures, Arrangements and Applications (NTAV/SPA); 2012 Sep 28-29; Łódź, Poland. The Institute; 2012. p. 143-7.

Song Y, Luo Y, Lin J. Detection of movements of head and mouth to provide computer access for disabled. In: 
Institute of Electrical and Electronics Engineers. Proceedings of the International Conference on Technologies and Applications of Artificial Intelligence (TAAI);2011 Nov 11-13; Chung-Li, Taiwan. The Institute; 2011.p. 223-6, https://doi.org/10.1109/TAAI.2011.46.

12. Al-Rahayfeh A, Faezipour M. Eye tracking and head movement detection: A state-of-art survey. IEEE J Transl Eng Health Med. 2013;1:2100212, https://doi.org/10.11 09/JTEHM.2013.2289879.

13. Singh H, Singh J. Human eye tracking and related issues: A review. Int J Sci Res Publ. 2012;2(9):1-9.

14. D’Orazio TD, Maranir R, Renò V, Cicirelli G. Recent trends in gesture recognition: How depth data has improved classical approaches. Image Vis Comput. 2016;52:56-72, https://doi.org/10.1016/j.imavis.2016.05.007.

15. Soileau L, Bautista D, Johnson C, Gao C, Zhang K, Li X, et al. Automated anthropometric phenotyping with novel Kinect-based three-dimensional imaging method: Comparison with a reference laser imaging system. Eur J Clin Nutr. 2016;70:475-81, https://doi.org/10.1038/ejen. 2015.132.

16. Han J, Shao L, Xu D, Shotton J. Enhanced computer vision with Microsoft Kinect sensor: A review. IEEE Trans Cybern. 2013;43(5):1318-34, https://doi.org/10.1109/TCYB.2013.2265378.

17. Levac D, Espy D, Fox E, Pradhan S, Deutsch JE. "Kinecting" with clinicians: A knowledge translation resource to support decision making about video game use in rehabilitation. Phys Ther. 2015;95(3):426-40, https://doi. org/10.2522/ptj.20130618.

18. Levinger P, Zeina D, Teshome AK, Skinner E, Begg R, Abbott JH. A real time biofeedback using Kinect and Wii to improve gait for post-total knee replacement rehabilitation: A case study report. Disabil Rehabil Assist Technol. 2016;11(3):251-62, https://doi.org/10.3109/17483107. 2015.1080767

19. Shotton J, Sharp T, Kipman A, Fitzgibbon A, Finocchio M, Blake A, et al. Real-time human pose recognition in parts from single depth image. Commun ACM. 2013;56(1): 116-24, https://doi.org/10.1145/2398356.2398381.

20. Palacios-Ceña D, Ortiz-Gutierrez RM, Buesa-Estellez A, Galán-Del-Río F, Cachon Perez JM, Martínez-Piedrola $\mathrm{R}$, et al. Multiple sclerosis patients' experiences in relation to the impact of the kinect virtual home-exercise programme: A qualitative study. Eur J Phys Rehabil Med. 2016;52(3):347-55.

21. Chang YJ, Chen SF, Huang JD. A Kinect-based system for physical rehabilitation: A pilot study for young adults with motor disabilities. Res Dev Disabil. 2011;32(6): 2566-70, https://doi.org/10.1016/j.ridd.2011.07.002.

22. Galna B, Jackson D, Schofield G, McNaney R, Webster M, Barry G, et al. Retraining function in people with Parkinson's disease using the Microsoft Kinect: Game design and pilot testing. J Neuroeng Rehabil. 2014;11:60, https://doi. org/10.1186/1743-0003-11-60.

23. Giorio C, Fascinari M. Kinect in motion audio and visual tracking by example. Birmingham: Packt Publishing Ltd.; 2013.

24. Microsoft [Internet]. Redmond: Microsoft; 2016 [cited 2016 Mar 18]. Kinect for Windows SDK v1.8. Available from: https://www.microsoft.com/en-us/download/ details.aspx?id $=40278$.

25. Microsoft [Internet]. Redmond: Microsoft; 2016 [cited 2016 Mar 18]. Tracking modes (seated and default). Kinect for Windows 1.5, 1.6, 1.7, 1.8. Available from: https://msdn.microsoft.com/en-us/library/hh973 077.aspx.

26. Microsoft, Xbox [Internet]. Redmond: Microsoft; 2016 [cited 2016 Mar 18]. Room lighting conditions for Kinect. Available from: https://support.xbox.com/en-US/xbox-360/ accessories/lighting.

27. EN 12464-1:2011. Light and lighting. Lighting of work places. Part 1. Indoor work places. Brussels: European Committee for Standardization; 2011.

28. ISO 9241-411:2012. Ergonomics of human-system interaction - Part 411: Evaluation methods for the design of physical input devices. Genewa: International Organization for Standardization; 2012.

29. MacKenzie IS, Tanaka-Ishii K. Text entry systems: Mobility, accessibility, universality. San Francisco: Morgan Kaufmann; 2007.

30. Soukorefi RW, MacKenzie IS. Metrics for text entry research: An evaluation of MSD and KSPC, and a new unified error metric. In: Association for Computing Machinery. Proceedings of the ACM Conference on Human Factors in Computing Systems (CHI); 2003 Apr 5-10; Florida, USA. New York: The Association; 2003. p. 113-20, https://doi.org/10.1145/642611.642632.

This work is available in Open Access model and licensed under a Creative Commons Attribution-NonCommercial 3.0 Poland License / Ten utwór jest dostępny w modelu open access na licencji Creative Commons Uznanie autorstwa - Użycie niekomercyjne 3.0 Polska - http://creativecommons.org/ licenses/by-nc/3.0/pl/deed.en. 